\title{
GIFTEDNESS: THE ANSWER IN ONE AND A HALF CENTURIES
}

\author{
Diana B. Bogoyavlenskaya \\ Psychological Institute, Russian Academy of Education \\ Moscow
}

\begin{abstract}
This article stresses the social importance of the problem of giftedness and in this connection the necessity to clarify this concept scientifically. The history of this problem reveals the origins of reduction of the concept and the wide-spread notion of giftedness as "intelligence level above average." There are two reasons of it: 1) Galton's components of giftedness were put into a complex; 2) there were no measuring techniques of this complex. The unit of the analysis of giftedness was formed after Galton's notion of giftedness as comprised of components was supplemented with the method of measurement - "systematic observation" - and understood as an ability to generate activity at one's own initiative. Then it became possible to realize Galton's concept of giftedness as a manifestation of mind and character.
\end{abstract}

Keywords: giftedness, systemic quality, reduction, method, diagnostics, elementwise approach, unit of analysis, personality, scaling, abilities, development, genius.

\section{Relevance of the problem}

Literature review on the issues of giftedness reveals their close link with direct demands of society. This trend is more obvious in American sources. Literature analysis of the last half century evidently shows that social and economic needs of society are dominating educational strategies: society turns a blind eye on educational shortfalls during one period, and then, speculating on them, calls forth another, alternative strategy.

In the 50s two opposite tendencies existed in the USA. On the one hand, availability of workplaces in the employment sphere during the period of stability caused lowering school age for children. On the other hand, the demographic explosion evoked numerous works indicating negative effect of lowering school age. 
In the 60 s educational values changed again. Pedagogical efforts shifted from talent development to children with developmental disorders. There was an argument in the scientific literature about human dignity and its right of realization. The search and the procedure in the discovery of talents were perceived as a coercive measure.

From the middle of 70 s a new surge of interest in educational acceleration was caused by growing worries and discontent of the American nation with the level of secondary education and fears to lag behind their industrial competitors. That was the reason to abolish strict recommendations in the contents of school disciplines. Public showed discontent with the exceeding fixation of schools on emotional well-being of children at the expense of decrease in academic load and hence in intellectual potential. Therefore, it is easily seen that changes in philosophical concepts of education and specific pedagogical strategies depend on social and economic reasons (Kuznetsova, 1996).

Soviet school faced challenges that arose from problems in realization of the law on general and compulsory secondary education. In the first place, the attention was focused on the children who had difficulties in knowledge acquisition (at least 1/3 of all students). Huge work was undertaken in detecting children with mental retardation. This general tendency to educate those who lagged behind remained a constant problem of that educational system. In such conditions it was a gifted child who often became an outcast of the educational process. At best, his abilities were exploited, at worst - suppressed.

For the first time the idea to create intellectual elite and acknowledgement that children are not equal in their abilities emerges in our country during Perestroika. Special focus on work with gifted children compensated longstanding oblivion of this problem and restored the duty to work with everyone. Though there were some fluctuations in intensity of the given campaign as it came "from above" and depended on the general social and economic situation in the country and on reforms in the educational system, the interest to this problem remained fairly stable.

As the society had switched to market economy, the motto of Perestroika changed to a claim to nurture competitive personality. To date, the economic model of competitiveness is usually taken, where the presence of a competitor stimulates development, so competitive children are put into focus of teaching process, while the rest of the students are not viewed as significant subjects. 
This call to nurture a competitive personality stimulates ambitions for early achievements, high ratings, victories in various contests. What are the means to solve this problem? One of them is lowering the age of participation in different competitions, for example, Selkunčik (Nutcracker - a contest of young musicians), contests of researchers and inventors, in which even 5 year old preschoolers may take part. The main argument of these events' initiators is that we live in the society with market economy and children should be included in competitive relations from the very beginning.

Various victories are usually viewed as self-actualization, which is in turn understood as the main task in the development of a gifted child. One must admit that contests and Olympiads are necessary and they have some advantages: they foster composure, perseverance, moderation. But overall, contests are the means of realization and demonstration of achieved potential. And, according to A.N. Leontiev, in such cases a "shift of motivation" from a goal to a task may occur. Victory becomes an end in itself and requires mechanisms different from those that are needed for child's development. Moreover, these events can not be viewed as means and ways of development of giftedness, though such attempts are undertaken. In this respect, the concepts of goal and means should be clearly specified.

Competitive personality is a personality with rich resources, more resourceful than others. In this context, gifted children are a resource for solving this problem. That's why the task of theoretical justification of the concept of giftedness is so important.

\section{Definition of the concept "giftedness"}

In 1998-2003 a team of scientists under my guidance developed the Operational Concept of Giftedness. It was done at my initiative and with organizational and scientific support of Deputy Minister of Education of the Russian Federation, Member of the Russian Academy of Education V.D. Shadrikov. The Concept offered practicians a unified, scientifically based, systemic conceptual framework. The systemic quality of the notion was emphasized. Here is the definition: "Giftedness is a systemic, developing during life course quality of mind, which determines a possibility for a person to achieve higher (unusual, remarkable) results in one or several activities, as compared to other people" (Bogoyavlenskaya 
\& Shadrikov, 2003, p. 5). Therefore, the given definition of giftedness enables us to step away from a customary notion of giftedness as a quantitative degree of abilities' expression that has developed at a certain stage and to grasp giftedness as a systemic quality. It should be noted that the term "systemic" is different from the notion of complex as a sum of components. System implies the process of integration, i.e. the whole has a new property as compared to the properties of its components. Our classics acknowledged that the concept of giftedness may be developed within the framework of systemic approach. S.L. Rubinstein wrote in 1935: "Giftedness cannot be identified with the quality of one function - even to cognition. Functions are the work of a far-reaching analysis, which evolves independent psychological processes... Giftedness, as well as character, determines more composite, complex properties of personality" (Rubinstein, 1935, p. 480). Later B.M. Teplov came to a similar conclusion: "This characteristic of personality that we call 'giftedness' is not to be seen as a simple sum of abilities: in comparison with abilities it constitutes a new quality" (Teplov, 1961, p. 103). According to Teplov, we cannot understand giftedness if we restrict ourselves merely to the analysis of specific abilities and particular qualities of creativity. In his analysis of creative techniques of genius musicians Teplov points at their personality characteristics. He reckons that only a person of high spirituality, wide intellectual and emotional range may become a significant musician (Teplov, 1961).

As a matter of fact, in the Concept we realized a tendency that has steadily been growing during the last half century. It coincides with the change of the stages of development of science itself, its readiness to change from abstract level of research to a more whole reconstruction of reality. This tendency of holistic approach to personality research is a natural stage of making psychological science. In one of his last books V.D. Shadrikov writes that time has come to switch from the globalanalytic approach of deconstruction of mind to the "synthesis of stored knowledge, a doctrine of holistic mind on the basis of systemic approach" (Shadrikov, 2006, p. 9).

Giftedness pertains to that kind of psychological problems, which can not be solved without a holistic personality approach; such phenomena can not be captured without this framework. It is claimed in the Concept that especially bright giftedness or talent speaks not only for high abilities in the whole set of components needed for an activity, but, 
which is more important, for the intensity of integrative processes "inside" the subject that involve his / her sphere of personality. Their intensity and wholeness determine the dynamics of individual development of giftedness. Regression of these processes explains the disappearance of giftedness (Bogoyavlenskaya \& Shadrikov, 2003, p. 6).

\section{Historical analysis of the issue}

One may object that everything can be described as a system, even its components. But the aim of the assertion of systemic nature of giftedness was to interpret on contemporary theoretical basis the ideas on the nature of giftedness, which were put forth by F. Galton. In his opinion, genius is a combination of the three important components - talent (as the highest manifestation of mind), character (as the manifestation of personal and motivational traits that ensure its realization) and stamina, ability to work hard (as an energetic factor). He highlighted talent and character as the substantial terms that "settle" genius, for "they embrace all human spiritual nature, as far as we can understand it. There is no other class of known qualities that may be put above them" (Galton, 1865 , p. 322). For Galton, giftedness "in wide sense" consists not only of "intellectual force" and emotional-motivational component, but it also includes commitment, which is highly characteristic of humans (further he explains it as inner motivation).

When nowadays giftedness is reduced to intelligence "above average," one emphasizes means, but omits the core of what constitutes giftedness. Why is the essence of the term "giftedness" lost? However sad it maybe, but it was Galton himself who set the stage for the departure from this concept.

According to Galton, reputation, or deep public acceptance, is the sum total that takes into account all manifestations of genius. He analyzed prominent English family clans in order to support his evidence of genius inheritance and assuming that social status is its strong marker. He had to formalize this body of data. To accomplish this, he had to measure, i.e., to match a large amount of various characteristics with corresponding entities.

Galton found information about the downside of high intelligence in the works of psychiatrist Seguin. It allowed Galton to state continuity of the distribution of inborn aptitudes. This introduction of continual 
distribution of abilities' manifestation in population was critical for the development of the measuring approach. Galton stated the coincidence of pithy interpretations of reputation (as the highest manifestation of genius) and abilities. While matching two classifications - of genius and abilities - he found similar tendencies of distributions of their manifestations in population and assumed that for the most part intelligence manifests genius.

Galton's research is fundamental; it revealed the problem in its complexity and those original contradictions that accompany its solving from the $19^{\text {th }}$ to the $21^{\text {st }}$ century. It is as if Galton mapped out some Scylla and Charybdis, and all the subsequent scientists tumble between them. All of them included personality, its spiritual element, in their concept of giftedness. According to C. Jung, the gifted person is the one "who carries cresset" (Jung, 2006). G. Revesh encourages: "we have to protect gifted people, those, who devote their energy to extension of their spiritual and moral life," but observes at once: "The main difficulty in detecting qualities characteristic of giftedness is that only intellect can be consistently studied so far, while other qualities may be just accidentally watched" (Revesh, 2006, p. 11). V.M. Ekzemplyarsky envisaged the detection of giftedness not only abundantly clearly, but also intrinsically truly. He stressed that he had aimed to determine the main core of what constitutes giftedness. He wished to understand giftedness as some solid complex, not as a sum of detached functions. He pointed straight at the "Gordian knot" of the problem: "We would like to leave just the word 'giftedness' in the designation of the problem, keeping in mind that our ideal task is to estimate the height of the development of all the main qualities of mental life: intellectual, emotional, volitional. We lack experimental methods to estimate emotional and volitional spheres, but quantitative methods for studies on intellect, on the contrary, are well-developed, so they limit the solving of the problem to intellectual sphere. We have to consider this constriction in clarification of the problem and of the methods of its solution" (Ekzemplyarsky, 2006, p. 264).

W. Stern was in charge for the whole stage in understanding and measuring of giftedness. His view was coherent: the need to measure had led to the narrowing of the term "giftedness": "We do not only separate mental giftedness from emotional and volitional qualities of the individual, but we also clearly distinguish it from other intellectual func- 
tions" (Stern, 1997, p. 58). As a result, this constricted view on giftedness and its reduction to measuring of IQ had ruled in psychology for many decades.

Thus, the clarification of the concept is determined by the methods of measurement. The fact of the reduction of the whole to its part lies at the heart of the tendency that L.S. Vygotsky called "elementwise analysis." But "when one equals the whole to its parts, one does not solve the problem, one just avoids it" (Vygotsky, 1982, p. 12).

Moreover, this tendency can be clearly traced throughout the $20^{\text {th }}$ century in the classification of the types of giftedness, which withdraws us from the solving of the problem. The division of giftedness into academic, intellectual and creative types has rooted both into practice and theoretical works, so we have to dwell on this question.

\section{Theoretical and methodical basis} of classification of giftedness

While accumulating the psychometric data on intellect it became clear that testologists were really far from measuring creativity. "The most massive testing program in history" (Feldman, Csikszentmihalyi, \& Gardner, 1994, p. xi) conducted by Guilford showed that the possibilities for measuring intellect had tethered and created the base for the search of specific tests on creativity. But the borders of reality that these tests grasp are conditional and the initial definition of the phenomenon in question is absent, so its empirical study is conducted without any directing vector, by divergent "inspection" of attainable fields in all possible directions. The more qualities are measured, the better.

In his book 30 years after developing the model of intellect Guilford concludes: "There has always been a considerable interest in relationships between creativity and intellect, especially to the extent in which the latter explains the former. Unfortunately, 'intellect' has never been uniquely (unambiguously) defined. Moreover, the accumulation of facts shows that intellect is a multidimensional thing with lots of components that were discovered by factor analysis. Our next question is: Is it possible to view abilities that seem to be the components of creative talent as the components of intellect? If so, do they play any significant role among intellectual abilities?" (Guilford, 1988, p. 152). After considering all the known factors as belonging to intellectual category, including the 
abilities of fluency, flexibility, originality as well as sensitivity to problems, Guilford suggested the system of these factors and called it "the structure of intellect." 1 Thus, "creative thinking abilities find their logical place inside this system" (Guilford, 1988, p. 153). Therefore, the factors of creativity are included into the unified system of intellect; they constitute a part of it. Unlike the first tendency where creative abilities were identified with intellect, here they are its component. But although they are included in this structure, they do not influence the general nature of intellect. Guilford specified that this is a morphological, not a functional model, i.e., there is no hierarchy in it. All factors are not the components of this structure in full sense; so the structure has a nonadditive quality, i.e. the quality which is extrinsic to its components. In Guilford's structure all the factors are independent abilities. This creates an objective possibility to study factors represented in tests of "intellect," special tests on "creativity" and their discrete measures, which is actually seen in numerous comparative studies on creativity and intellect through the second half of the $20^{\text {th }}$ century. These studies are conducted in a triad, which includes learning ability (or professional success) as an indicator of real life validity of tests of intellect and creativity. These three indicators have become the basis of classification of talent into three separate types: academic (promptness and easiness of acquisition of large amounts of provided knowledge), intellectual, creative.

In practice we may find facts that support this typology. It is very popular nowadays to split giftedness into academic, general and creative, which can be explained as a fact that abilities per se are not synonymous to one's creative potential. Nevertheless the implicit dichotomy in the conception "acquisition of knowledge - generation of new knowledge and methods of application of existing knowledge" appears absolutely mechanistic. V. Kudryavtsev objected to this division of giftedness into academic, intellectual and creative, as in normal conditions creative exploits underlie academic achievements. The disciples of this classification have to bear in mind the notions of leading American experts: "The decisive question that creative abilities per se may have nothing to

1 For the first time the cube model as it is known today was presented by J. Guilford in 1958, when he was invited to give a speech at an annual meeting of the Western Department of Testing Services in Education, which for many years was the leading agency in testing abilities for college in the USA. 
do with school performance has never been raised" (Getzels \& Jackson, 1962, p. 6).

Even the followers of abovementioned classification acknowledge that in some cases the teacher may find it difficult to discern intellectual and academic types of giftedness since "both may study brightly, both have cognitive need. The difference is rather in a particular mental independence of intellectuals, their high censoriousness of cognition, ability to independently face global, philosophical understanding of sophisticated intellectual problems. Academically gifted students are always geniuses of a teacher, sui generis brilliant professionals of school (and then - university) work, superb masters of prompt, stable and qualitative acquisition" (Bogoyavlenskaya, 2004, p. 18). It turns out that on the one hand intellectual giftedness is characterized by independence, philosophical understanding of global problems, but it is not the creative giftedness yet. On the other hand, qualitative acquisition is impossible without independent reasoning. It appears that the suggested division of giftedness is too pragmatic and is more likely connected with the type of diagnostic procedure (marks, IQ and Cr tests). Consequently, the method of measurement defines the object, not contrariwise.

Herewith, the split of giftedness in three types corresponds to the understanding of the nature of creative abilities itself. It has changed from the direct identification to its direct contraposition (critical thinking slows down generation of ideas). According to the new approach factors of creative productivity exist in parallel with the factors that are traced in the tests of intellect and have its own localization (factors of divergent thinking). The detection by Guilford of the integrated index of creativity $\mathrm{Cr}$, which is different from IQ - index of intellect - illustrates the tendency that consists in "oscillation between full identification and equally metaphysical, equally absolute estrangement and detachment." Then one starts to establish between them "purely mechanistic dependence as between two different processes," which is characteristic of the "elementwise analysis" (Vygotsky, 1982, p. 12). On the one hand, this fact confirms the prognostics of Vygotsky's methodological principle and underlies the explanation in understanding creative abilities and giftedness developed in the $19^{\text {th }}-20^{\text {th }}$ centuries. On the other hand, his idea that psychology, which longs for studies of complex unities, must switch from methods of dissolution of elements 
to methods of unit analysis (Vygotsky, 1982, p. 12) calls for proper disclosure of the concept of giftedness and for extraction of the unit of its analysis.

\section{The unit of analysis of giftedness}

Enunciated in the beginning of the last century, this statement did not lose its relevance, but it is still in the "zone of proximal development" of psychology. The entrance into this zone is attained each time at the cost of crisis in the study of the problem and upon condition of sufficient maturation and exhaustion of an escalated conflict (which is implicitly indicated by the attempts to avoid it).

The difficulty of units' extraction leads sometimes to a conclusion that there are no units at all, or that they are just an ideological compromise. Nevertheless, an example of such work in Russian psychology has been given by D.B. Elkonin. He said: "Human objective action is Janusfaced. It contains both human sense and operational side. If you lose sense, it will cease to be an action; but if you throw away operationaltechnical side, nothing will be left of it... Therefore, there are these two sides in the unit of human behavior, and the unit of human behavior is goal-oriented conscious action. We should regard them as two sides, not as distinct and totally unrelated spheres of the world" (as cited in Elkonin B.D., 1994, p. 106).

As it was shown above, the main difficulty in understanding giftedness as a systemic quality lies in the impossibility of systematic observation of all its components: emotional, motivational, volitional, etc. Indeed, it is difficult to conduct systematic observation of all the components of the whole separately and simultaneously. Even with the fitting set of diagnostic methods this job is laborious, as it demands not only the consideration of an array of factors, but the extraction of those that ensure the "realization of mind." Yet it is possible, if "the whole" is captured by extraction of "the unit of analysis." It corresponds to L.S. Vygotsky's methodological ideas.

It seems it is agreed that giftedness manifests itself in the way one acquires and then develops activity. My understanding of giftedness is reflected in the book Operational Concept of Giftedness (Rabočâ̂ koncepciâ odarënnosti). Activity is always conducted by personality. One's goals and motives influence the level of accomplishment of activity. If personal goals lie outside the activity itself, for example a student prepares his or 
her homework exclusively in order not to be scolded for bad marks or not to lose his or her image of an excellent pupil, at best his / her activity is performed conscientiously, but even with the brilliant performance the result never exceeds normatively demanded product (Bogoyavlenskaya \& Shadrikov, 2003, p. 22). While noticing the abilities of such a child, one should not talk of giftedness, as the latter implies the dedication to the subject itself, absorption in work "commitment," according to F. Galton. In such a case the activity does not stop even when the initial task is over and the initial goal is realized. One constantly refines what one does with love; one realizes new plans that were generated in the process of work itself, i.e., one shows cognitive self-activity. As a result, one's new product of activity goes considerably beyond the initial plan. In this case we can say that the "development of activity" occurred. The development of activity at the initiative of a person oneself is creativity as a manifestation of giftedness. M. Gorky was ultimately precise in this thought: "It seems to me that inspiration is mistakenly considered as the instigator of work, it is likely to emerge in the process of successful work as its consequence... Talent is love of one's work. Talent develops out of the feeling of love of action; it is even possible that talent - in its essence - is merely the love of action, of work process..." (Gorky, 1936, p. 30).

When we judge giftedness by success in acquirement and development of activity, the terms "giftedness" and "creative giftedness" become synonymous. Thus, we do not view "creative giftedness" as a special, independent type of giftedness. Development of activity results in creative product, which eventually determines the value of giftedness per se. All at once, the ability to develop activity at one's own initiative can be viewed as the unit of its analysis and the operational disclosure of giftedness.

\section{Structure of giftedness}

In light of this, we appreciate Galton's discernment, for he grasped the essence of giftedness as the integration of mind with motivational and personality traits that provide the realization of the former. Indeed, our cross-sectional and longitudinal experiments show that general and specific abilities appear to be the real means of successful activity, but they do not unambiguously determine its developmental potential. Their contribution is realized through the motivational structure of personality, its value orientations. 
We have identified the two types of motivation. The first type provides the high level of cognitive self-activity and consists of cognitive motivation, interest to one's work, not to success, literally: "To give your all - this is creation, / And not all the fuss or success" (Pasternak, 1965). In general, cognitive need may exist even in reproductive version (erudite - "walking encyclopedia," or eye-catching inquisitiveness). Thus, M.M. Prishvin claimed, that "In this eager demand for new impressions that heat the imagination underlies immaturity of mind, superficiality. Sure enough one does not need to travel to Central Africa when outside Moscow one may find the world even less known," he wrote. "One should make discoveries near oneself; the closer one approaches oneself, the deeper one enters the treasure" (Prishvin, 1969, p. 70). But in its productive version it is accompanied by demand for one's own view of the world. One ought to draw more attention to this question, as teachers often cease to identify learning ability, which is swift and easy, but reproductive in its effects. The fact of a "good" learning ability itself, which is defined by criteria of speed and size, but exists within the limits of external motivation, appears to them as an indication of giftedness.

The oppositional viewpoint, according to Frankl, gives rise to specific sort of subjectivism, which he calls "kaleidoscopism": "Unlike binoculars or spyglass looking in the kaleidoscope one may see only kaleidoscope" (Frankl, 1990, p. 72). In this model of cognition a person produces merely his own world, sees merely him- or herself. That's why the final conclusion of Frankl is so logical: "Only to the extent that I recede into the background, bury in oblivion my own existence, I get the possibility to see something bigger than I am myself. This self-denial is a price I have to pay for the cognition of the world. In a word, I have to ignore myself" (Frankl, 1990, p. 73). If one fails to do it, one's cognitive possibilities suffer a loss, as one blocks the way to one's cognition.

Thus, the second type of motivation appears as the psychological barrier of manifestation of cognitive self-activity. It includes external motives towards cognition. In case of their dominance, focus on one's own personality, narrowness on oneself, cognitive possibilities of a person are blocked. Well-known physicist, member of the academy of sciences A.B. Migdal noted with regret that a lot of talents had died in sci- 
ence because of the impetuous urge to self-assertion and rush for showy results (Migdal, 1976).

A similar bind between creativity as a result, but not a goal, and consistently realized activity, which is developed if one sees the meaning of one's existence in it, is easily traced in V. Frankl's analysis. Therefore, the "arbitrary" development of activity, which is performed without a practical need, but of one's own free will, volition, - is the manifestation of a standpoint of the subject of activity, of the authorial attitude, of the authentic giftedness.

Therefore, in the first case the motives stimulate the realization of abilities, while in the second case they hamper them. Jaspers comments on the extreme situation: "Since the high rank is achieved by those who had immolated one's essence, they do not want to allow others to maintain it" (Jaspers, 1991, p. 312), i.e., he does not believe in the possibility of unselfish analysis of activity. Thereby we may explain facts when we do not observe the manifestation of cognitive selfactivity in people with the highest intellectual abilities, while people with the equal level of abilities differ in their creative potential - giftedness.

The appreciation of the necessity of the holistic view on giftedness is characteristic of some foreign scientists as well. Thus, E. Landau writes: "Sectional approach when each element is perceived separately deprives us of the possibility to see the whole... and therefore to perceive reality in its dynamics of actions and counteractions" (Landau, 2002, p. 134). In her book she compares sectional approach with the broken mirror. One may see something, but not the whole picture in each piece of it. It is dangerous that people rest content with partial knowledge and do not even try to conceive the whole, genuine picture. Indeed, in the absence of the initial definition to disclose the nature of the phenomenon in question its empirical study lacks the directive vector and provides only its partial representation.

The historical analysis of the problem of giftedness enables us to assert that the realization of the "holistic" approach can be virtually performed only with the extraction of the "unit of analysis" as the essential characteristic of its highest, grown form. In other cases any consideration of personality factors becomes haphazard and can not give the whole idea of giftedness. 


\section{The method of identification of giftedness}

It was shown in the foregoing discussion that the reduction of the concept "giftedness" had been determined by various types of measurement. Moreover, a concept cannot be operational, if it is not accompanied by the procedure of its identification. In accordance with that, the method of identification of giftedness as the ability to develop activity at one's own initiative has to contain two dimensions: a scalable fixation of a given activity and a scalable fixation of an outflow of activity beyond its demands into an unexpected sphere as a result of its development. To study the highest mode of creativity - "spontaneous discoveries" - I developed the psychodiagnostic method Creative field, which complies with the requirements and can be viewed as a valid method of identification of giftedness (D.B. Bogoyavlenskaya \& M.E. Bogoyavlenskaya, 2005). The method allows us to estimate not only the measure of manifestation of giftedness, but also its structural components on a considerable number of parameters in one material at once. It stands to mention that the parameters are represented not discretely, but in their integration, which provides the holistic representation of giftedness. One can see it visually, as a photo or, rather, an x-ray.

Then the question a rises: Why is it not sufficient merely to use standard psychodiagnostic methods for representations of personal qualities, motivations and mental abilities? It appears to us that the description is more effective in the framework of Creative field than in the isolated testing of discreet qualities, since we see at once not only their relative value, but their contribution into the formation of giftedness. The availability of the method has made giftedness in its wholeness a "systematically observed" phenomenon. "The Gordian knot" was cut.

\section{Dimensions (levels) of scaling giftedness}

In the dimension of a given activity the process of its acquisition is scored on a variety of parameters: generality, economy, independence of thinking, as well as the aspects of self-regulation and strategies of decision making (from chaotic to goal-directed). On this level the activity has a productive quality, but each time it is determined by the influence of an external stimulus. The initiative for further development of activity is hampered by the motives of the second type - "kaleidoscopism." Due to that, the highest expressions on this level correspond only to the 
high level of development of mental abilities (Bogoyavlenskaya, 2002). Actually, the phenomenology of this dimension complies with the concept of "general giftedness," which is wide-spread in psychological literature.

Nowadays, the persistent definition of giftedness as "intellect above average" by an array of specialists should be qualified as the conservative view, for it leads to insoluble controversies; it is illustrated by the historical analysis of the problem. This position contradicts the contemporary methodology and is most likely rationalized merely by the absence of proper means of measurement of the desired psychic reality.

The dimension of development of activity, where it becomes creative, corresponds to the predominance of motivation of the first type the prevalence of cognitive motivation in the structure of personality and selfless dedication to the performed activity. Scaling in this dimension is performed by fixation of open regularities (experimental material implies their hierarchy) and by their theoretical objectivation. The latter forms the basis for building a new theory by a person.

The adduced description of the levels of activity performance allows us to explain the facts why some people may have the highest intellectual abilities but lack creative abilities and why people with the same level of abilities vary in their creative potential. At the same time, the differentiation of productive phenomenology enables us to extract creativity and giftedness "in the strict sense of the word" from the sphere of productive processes, by analogy with W. James, who extracted cognition in the strict sense of the word from the sphere of mental processes.

Lastly, it must be emphasized that the proposed theoretical approach has got the important practical consequence: when one speaks of the development of giftedness, one should not limit one's work merely to compiling educational programs. It is essential to create conditions for generation of inner motivation of activity and the system of values, which create the base for making personal inwardness.

The existing and possible methods of work with gifted people in various educational institutions depend in their realization on understanding giftedness by the organizers themselves. Eventually, it determines the result: whether giftedness is developed or skills are honed and achievements here and now are shown. 


\section{References}

Bogoyavlenskaya, D.B. (2002). Psihologiâ tvorčeskih sposobnostej [Psychology of Creative Abilities]. Moscow: Akademiâ.

Bogoyavlenskaya, D.B. (Ed.). (2004) Odarënnyj rebënok, 4 [Gifted Child, 4].

Bogoyavlenskaya, D.B., \& Bogoyavlenskaya, M.E. (2005). Psihologiâ odarënnosti: ponâtiâ, vidy, problemy [Psychology of Giftedness: Concepts, Types, Problems]. Moscow: MIOO.

Bogoyavlenskaya, D.B., \& Shadrikov, V.D. (Eds.). (2003). Rabočaâ koncepciâ odarënnosti [Operational Concept of Giftedness]. Moscow: MO RF.

Ekzemplyarsky, V.M. (2006). Problema odarënnosti. Izmerenie odarënnosti kak teoretičeskaâ i praktičeskaâ problema [The Issue of Giftedness. Measurement of Giftedness as a Theoretical and Practical Problem]. In A.M. Matyushkin \& A.A. Matyushkina (Eds.), Čto takoe odarënnost' [What Giftedness Is] (pp. 262-318). Moscow: ČeRo.

Elkonin, B.D. (1994). Vvedenie v psihologiû razvitiâ [Introduction to Developmental Psychology]. Moscow: Trivola.

Feldman, D., Csikszentmihalyi, M., \& Gardner, H. (Eds.). (1994). Changing the World: A Framework of the Study of Creativity. London: Westport CT.

Frankl, V. (1990). Človek v poiskah smysla [Man's Search for Meaning]. Moscow: Progress.

Galton, F. (1865). Hereditary Talent and Character. Macmillan's Magazine, 12, 157-166, 318-327.

Getzels, J.W., \& Jackson, Ph.W. (1962). Creativity and Intelligence. London: Wiley.

Gorky, M. (1936). Pis'ma k rabkoram i pisatelâm [Letters to Reporters and Writers]. Moscow: Žurgazobedinenie.

Guilford, J.P. (1958). New Frontiers of Testing in the Discovery and Development of Human Talent. In Seventh Annual Western Regional Conference on Testing Problems (pp. 20-32). Los Angeles.

Guilford, J.P. (1959). Three Faces of Intellect. American Psychologist, 14, 469-479.

Guilford, J.P. (1967). Joy Paul Guilford. In E.G. Boring \& G. Lindzey (Eds.), A History of Psychology in Autobiography. Vol. V (pp. 167-191). New York: AppletonCentury-Crofts.

Guilford, J.P. (1988). An Odyssey of the SOI Model. Autobiography of Dr. J.P. Guilford. Tokyo.

Jaspers, K. (1991). Smysl i naznačenie istorii [The Origin and Goal of History]. Moscow: Politizdat.

Jung, C.G. (2006). Fenomen odarënnosti [The Phenomenon of Giftedness]. In A.M. Matyushkin \& A.A. Matyushkina (Eds.), Cto takoe odarënnost' [What Giftedness Is] (pp. 41-55). Moscow: ČeRo. 
Kuznetsova, Yu.I. (1996). Izučenie $i$ obučenie odarënnyh detej v amerikanskoj pedagogičeskoj psihologii XX veka [Study and Education of Gifted Children in the American Educational Psychology of the $20^{\text {th }}$ Century] (Candidate of Sciences dissertation). Nizhny Novgorod.

Landau, E. (2002). Odarënnost' trebuet mužestva [Giftedness Calls for Courage]. Moscow: Akademiâ.

Migdal, A.B. (1976). Psihologiâ tvorčestva [Psychology of Creativity]. Nauka $i$ $z \check{z} i z n$ ', 2, 100-107.

Pasternak, B.L. (1965). Stihotvoreniâ i poèmy [Selected Poems]. Moscow: Sovetskij pisatel'.

Prishvin, M.M. (1969). O tvorčeskom povedenii [On Creative Behavior]. Moscow: Sovetskaâ Rossiâ.

Revesh, G. (2006). Rannee proâvlenie odarënnosti i eë uznavanie [Early Manifestation of Giftedness and its Recognition]. In A.M. Matyushkin \& A.A. Matyushkina (Eds.), Cto takoe odarënnost' [What Giftedness Is] (pp. 5-40). Moscow: ČeRo.

Rubinstein, S.L. (1935). Osnovy psihologii [Foundations of Psychology]. Moscow: Učebno-pedagogičeskoe izdatel'stvo.

Shadrikov, V.D. (2006). Mir vnutrennej žizni čeloveka [Man’s World of his Inner Life]. Moscow: Logos.

Stern, W. (1997). Umstvennaâ odarënnost' [Mental giftedness]. Saint Petersburg: Soûz.

Teplov, B.M. (1961). Problemy individual'nyh različij [Issues of Individual Differences]. Moscow: APN RSFSR.

Vygotsky, L.S. (1982). Sobranie sočinenij [Collected Works]. Vol. 2. Moscow: Pedagogika. 